\title{
Learning Preferences among Medical and Physical Therapy Students: A Systematic Review
}

Sarwat Ali, Ashfaq Ahmad, Arooj Munawar, Muhammad Waqas

\begin{abstract}
Learning style is known as affective, cognitive, physiological, or combined characteristics which indicate the ways through which students interact, respond and understand the learning environment. A systematic review was conducted with relevant literature from 2012 to 2021 by hand searching and from electronic databases (PubMed, MEDLINE, ProQuest, and Eric) with proper search strategy as Boolean operator. They were searched using the keywords 'allied health students' 'learning style', 'medical students', 'MBBS students' and 'physical therapy students OR physiotherapists'. Out of 1027 studies, only 16 potentially relevant articles were included in this review. This study reflected undergraduate physical therapy and MBBS students from various countries and their most preferred learning style is kinaesthetic and activist which states learning is based on experiments, hands-on practice, audio-visual lectures, teaching sessions in a new environment allowing students to analyze and synthesize theories. However, students require adaptable, educative, and assessment strategies as they have different learning styles.
\end{abstract}

Keywords: Allied health, Learning style, Learning style, Medical students, Physiotherapy, Questioner.

How to cite this Article:

Ali S, Ashfaq A, Munawar A, Waqas M. Learning Preferences among Medical and Physical Therapy Students: A Systematic Review. J Bahria Uni Med Dental Coll. 2022; 12(1):46-53 DOI: https://doi.org/10.51985/JBUMDC2021070

- - - - - - - - - - - - - - - - - - - - - - - - - - - - - - - - - - -

This is an Open Access article distributed under the terms of the Creative Commons Attribution Non Commercial License (http:// creativecommons/org/licences/by-nc/4.0) which permits unrestricted non commercial use, distribution and reproduction in any medium, provided the original work is properly cited.

- - - - - - - - - - - - - - -

\section{INTRODUCTION:}

Learning style is known as affective, cognitive, physiological, or combined characteristics which indicate the ways through which students interact, respond and understand the learning environment. Different learning inventories are used which are predicted through information-processing models to describe any individuals' assimilating information from an intellectual approach. ${ }^{1}$ In writing, learning style is characterized as "a bunch of elements, practices, and

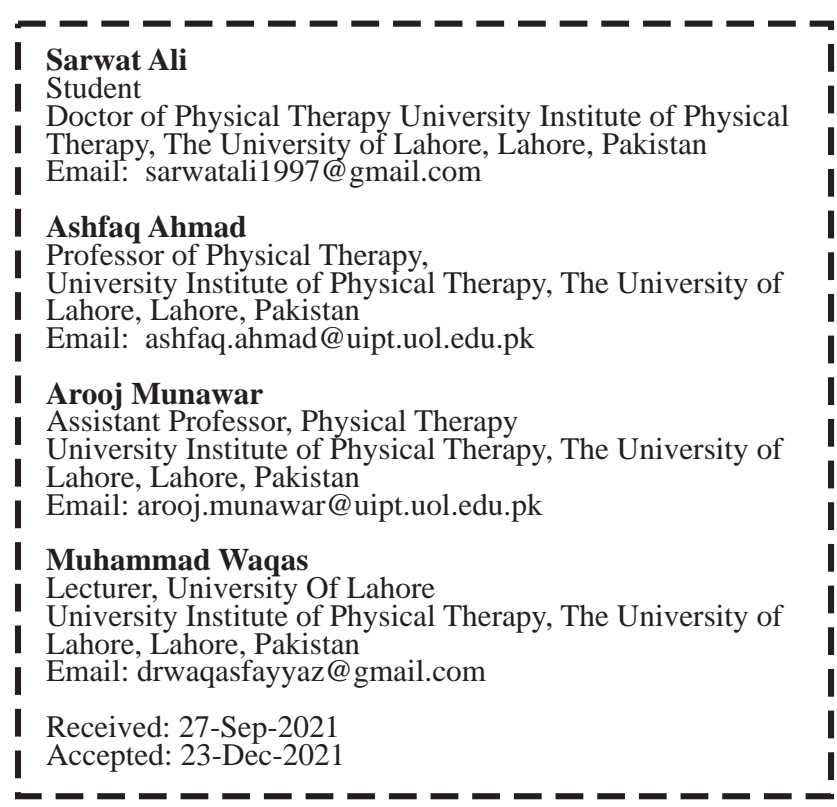

mentalities that make learning simpler for a person in a given circumstance" and is additionally characterized as "in the feeling of learning, the reasonable manner by which individuals react to and use stimulation", 2,3

In both classroom curriculum and layout, learning style has always played a key role. Its mechanism is the creation of comprehensive understanding as part of the evolution of knowledge. It's vital to find out how students think to spread the information about certain subjects. It can also be used to plan, design, develop, and disseminate instructional and support services. It will also empower, stimulate, integrate, teach, and broaden students' professional awareness. Understanding the learning pattern can help with the design and delivery of learning stryegies that are suitable for the students. ${ }^{4}$

When researching learning styles, it can be shown that learning style preferences are distinct. Although some people tend to use a particular learning style, others prefer to use more than one learning style and both choices lead to having a more successful learning experience. ${ }^{5}$ Knowledge perception, interpretation and absorption are described as the learning style, which has been created by several instruments and mechanisms for studying and labelling or classifying any particular learning way. ${ }^{6}$

A style of learning determines a method of choice and is called an umbrella concept that encompasses a variety of interests and techniques. The concept of learning style is found in the broader concept of personality. One's learning 
style is neither superior nor similar to another; rather, it is different, with distinct strengths and limitations. Understanding learning patterns should be used to help learners and tutors become more self-aware about their abilities and limitations as learners. In addition, the logic of lifelong learning shows that students are more driven to learn as learners by understanding more of their abilities and shortcomings. ${ }^{7}$

Multiple learning style models have been adapted and designed on lower levels however they are not widely acknowledged. About 9 of the 71 models described were good enough to incorporate concepts such as Kolb Learning Model, Learning Styles Inventory (LSI), Honey and Mumford's Learning Styles Questionnaire, Riechmann and Grasha's Learning Interaction Model Style, Gregorc's Style Delineator, VARK (Visual, Aural, Reading/ writing, Kinesthetic), VAK, Felder-Silverman model. ${ }^{8}$

The model of the Kolb's learning style is a famous instrument which was designed to measure a group of emotion-related activities. It involves reflecting, thinking and doing, which means that any of the four key learning skills that any person can use (AE) active experiment, (AC) abstract conceptualization, (RO) reflective evaluation, and (CE) specific experience. On average, any individual may develop a specialized preference, which will be known as a learning style, for their skills and activities. We have to understand that any single specialization is not inferior or more preferable to another because according to character, strength, and weakness, each of them is distinct. ${ }^{9}$

For these categories of students, Honey and Mumford suggested a grouping of academic styles into activists, reflectors, theorists, and pragmatists. Each of these learning methods has its own set of teaching designs. Honey and Mumford illustrated that Pragmatic learners learn when learning challenges are practical and concrete. The activist will learn when an environment is a new, varying, and continuing action. Reflectors learn better as learning experiences give them the ability to think about what is being learned and reflect on it. Theorists learn when they have time to analyze and synthesize theories. The use of accurate, sensitive, and detailed psychometric tools to assess and consider learning styles is a major challenge in learning style study. ${ }^{10}$

The LSI (learning style inventory) and the LSQ (Learning Style Questionnaire) are the two most comprehensive psychometric instruments endorsed, assessing the learning patterns of Honey and Mumford and Kolb (LSQ). In various studies, the validity and reliability of the Learning Style Questionnaire differ, but it has been found to be better than the learning style inventory. The statistical validity of the Learning Style Inventory is stronger. The Learning Styles Questionnaire (LSQ) is widely regarded as a more valuable and effective tool for assessing students' learning styles from various backgrounds. LSQ data can be effectively used to generate appropriate and relevant learning experiences and learning methods.

GRLSS (Reichmann and Grasha's Student Learning Style Scale) categorizes students based on the type and intensity of their interactions. The learning interface style focuses on the preference of the student but it also includes dimensions of affective and social in the style of measurement. The model explains various dimensions which are the avoidantparticipant, competitive-collaborative, and dependentindependent. The GRLSS is a questionnaire that is presented in two categories, one for the assessment of class and one for the assessment of the individual style.

The Style Delineator from Gregorc described four behaviours distinctively: sequential, concrete, random and abstract. The individual style is indicative of a combination of these tendencies. Gregorc believes that this pattern reflects born predispositions, but people must be able to function outside of their instinctual genre. There are Four learning styles Concrete sequential learning is portrayed by direct, bit by bit, systematic, tactile based learning; concrete random learning is portrayed by experimentation, instinctive, and autonomous learning draws near; the abstract sequential study is characterized by coherent, rational approaches and a predisposition for verbal injunction; and abstract random learning is characterized by a preference for coherent, visible, trained, and verbal instruction. This Style Delineator is a Forty-item inventory of individual reporting containing the ranking of a set of words.

VARK (Visual, Aural, Reading/ writing, Kinesthetic) is a questionnaire formed by Neil Fleming, an educator, and instructor in New Zealand, who implemented a model for differential learning, consisting of 16 multiple-choice questions. ${ }^{11} \mathrm{He}$ described the 4 sensory aspects. Visual learners learn through figures, diagrams, movies, images, and layouts. Aural students learn through seminars, discussions, small-scale learning, and speeches. Learners with a reading/writing style learn through books, lecture books, and notes. Kinesthetic learners learn through demonstration, touch, and experience, physical actions, mock-ups, case-based learning, group visits, role plays, and working with their hands.

Using the Felder-Silverman model a large number of studies have looked at the learning style characteristics of medical students. Auditory, visual, and sequential learning is the most commonly identified types of learning by medical students, according to research. ${ }^{12}$ Besides, a few investigations have found that clinical understudies are prone to a reflective learning style. ${ }^{13,14}$

The Axis tool is to be used to evaluate observational crosssectional studies. It aims at dealing with problems that often occur in cross-sectional studies and at helping the reader determine the quality of the study. The tool aims to aid in 
the analysis of the observational cross-sectional studies used in a systematic review and to give suggestions about the quality of research. ${ }^{15}$

At present, many different learning style inventories and questionnaires are used to check the learning style preference among students of varied professions from various countries. But there are no specific recommendations to use which model to assess the preferred learning style. The purpose of this review is to gather all the information about the learning styles of medical students and then appraise which learning style is the most preferable among medical and physiotherapy students.

\section{Methodology:}

A systematic review was conducted according to PRISMA guidelines as EQUATOR network follow. Relevant articles published between years 2012 to 2021 were located using the following databases including PubMed, MEDLINE, ERIC, and ProQuest Search strategy was used for each database by combining the following MeSH terms and Key Words: 'Learning style', 'physiotherapy', 'allied Health', 'academic performance', 'medical education', 'VARK', 'Learning preferences', 'Kolb', 'learning methods', 'learning style questionnaire', 'medical students', 'effective learning' and boolean operators i.e. AND, OR and NOT related to the objective of study. Full-text articles were retrieved for eligibility or in case if a conflict exists in any article then authors have to decide whether to include it or not in the study. Indexing terms, synonyms were used and filtered applied: Full text, observational studies, and English and relevant information from the study was extracted and reviewed by the authors. A Prisma flow diagram (Figure 1) is used to show how the articles were searched and included in the study. Studies were included only when: (i) Only medical and allied health student's e.g., DPT and MBBS. (ii) Study design was observational, cross-sectional studies. (iii) Full-text articles. (iv)Participants were undergraduate students. (v) Peer-reviewed. (vi)Professional and scientific journals. (vii) If it contains any standardized questionnaire for assessment. (viii) Studies included without language restriction (ix) Published in the year 2012 till 2020. Studies to be excluded when: (i) if the participants were other than medical and allied health students. (ii) Any other form of study design. (iii) Studies not using standardized questionnaire (iv) If older than the year 2012. (v) No full-text article.

Search records were saved in EndNote X7 software. Duplicate records were removed after that different screening of articles was conducted based on abstract and full-text articles. At the end, final text articles which were included from different databases were used to create tables that describe different variables like methodology, sample size, demographic data. A table was created to describe the different studies characteristics and studies were managed according to quality scores.
In order to evaluate the methodological quality of all studies the critical assessment AXIS tool created by Downes MJ et al. with Delphi methodology was used. ${ }^{16,17}$

The AXIS tool, which was formed in 2016 and contains 20 items, is a critical assessment method for cross sectional studies which discusses the design and quality of studies and the risk of bias in cross-sectional studies.

Outcomes of interest: Outcome measures included: Different versions of Kolb's LSI (Learning style inventory), GRLSS (Grasha-Riechmann learning style scale), The VARK (Visual, Aural, Reading/ writing, Kinesthetic) questionnaire, Gregorc style delineator, Felder Silverman's ILS (Index of learning style) and Honey and Mumford's Learning Style Questionnaire.

\section{RESULTS:}

Initially, 1033 studies were found through PubMed, Eric, ProQuest, and MEDLINE databases as well as through other records identified through Hand searching. Total 234 out of 1033 studies were removed because of duplication records. 799 studies/articles were examined for acceptability based on the title and abstracts of studies. Total 60 studies were included. 697 studies were excluded which did not meet our inclusion criteria. For the eligibility of studies 42 full-text articles were assessed out of which finally 16 studies were included for study analysis and synthesis and results were drawn.(Fig:1)

The Result is summarized in Tables. Demographic data like participants or sample size, country, and population of included studies and Methodological Characteristics of included studies like Learning style theories/ models and learning style identified are drawn in Table 1. The critical appraisal tool developed by Downes MJ, et al. using Delphi methodology was used to assess the methodological quality of all studies. Which was formed in 2016 and contains 20 items, is a critical assessment method which discusses the design and quality of studies and the risk of bias in crosssectional studies. The whole quality of each article was evaluated by twenty closed-ended questions. Each question was marked as 1 or 0.1 for totally fulfilled criteria and 0 for not fulfilling criteria.

The AXIS tool which is the Critical Appraisal method for cross-sectional studies is made up of 20 close-ended questions. In the Axis Tool, the following seven questions dealt with the reporting quality $(1,4,10,11,12,16$, and 18), and the other seven questions dealt with the study design $(2,3,5,8,17,19$, and 20) and the rest six questions dealt with the possibility of risk of biasness being introduced into the study $(6,7,9,13,14$ and 15). (Table 2)

The study looked into the current evidence for medical students' preferred learning styles. This review showed that the 16 studies which evaluated the learning style preferences the most commonly used questionnaire was VARK (Visual, 
Aural, Reading/ writing, Kinesthetic) which was used in six studies having kinaesthetic type followed by The Honey and Mumford which had activists style found to be commonly used in three studies and among six studies two using Kolb's learning style inventory had assimilating style, two used the Grasha-Riechmann learning style scale which had both dependent independent along with collaborative style and two studies used Index of learning style in which visualverbal aspect was found. While only one study used Gregorc Style Delineator in which most physical therapist students preferred concrete-sequential learning styles.

\section{DISCUSSION:}

The study's purpose was to look into the current evidence for Medical and Allied health student's preferred learning styles. We included 16 studies with 2616 participants. This review showed that 16 studies evaluated the learning style

Table 1: Summary table of included studies

\begin{tabular}{|c|c|c|c|c|c|c|}
\hline NO & $\begin{array}{l}\text { Study Author } \\
\text { (Latest to old) }\end{array}$ & Country & Participants & Population & $\begin{array}{l}\text { Learning style } \\
\text { theories / models }\end{array}$ & Learning styles identified \\
\hline$\overline{1}$ & $\begin{array}{l}\text { (WNI Kularathne } \\
\text { et al., 2020) }\end{array}$ & Sri Lanka & 112 & $\mathrm{Ug}, \mathrm{Dpt}$ & $\begin{array}{l}\text { Honey and Mumford, } \\
\text { LSQ }\end{array}$ & Activist learning style. \\
\hline 2 & $\begin{array}{l}\text { (Amtul Anum } \\
\text { et al., 2019) }\end{array}$ & Pakistan & 278 & $\begin{array}{l}\text { Ug, Dpt, } \\
\text { Mbbs, Bds }\end{array}$ & VARK & Unimodal, Kinesthetic \\
\hline 3 & $\begin{array}{l}\text { (Assad Ali Rezigalla } \\
\text { et al., 2018) }\end{array}$ & Saudi Arabia & 136 & $\mathrm{Ug}, \mathrm{Mbbs}$ & VARK, Version 7.1. & Unimodal, Aural. \\
\hline 4 & $\begin{array}{l}\text { (D A Shead } \\
\text { et al., 2018) }\end{array}$ & South Africa & $\begin{array}{l}\text { group 1: } 59 \\
\text { group 2: } 54\end{array}$ & $\mathrm{Ug}, \mathrm{Dpt}$ & GRLSS & $\begin{array}{l}\text { Dependent style for group } \\
1 \text { and the Independent style for group } 2\end{array}$ \\
\hline 5 & $\begin{array}{l}\text { (Nursen Ýlçin } \\
\text { et al., 2018) }\end{array}$ & Turkey & 217 & $\mathrm{Ug}, \mathrm{Dpt}$ & GRLSS & Collaborative learning style \\
\hline 6 & $\begin{array}{l}\text { (Daniel Hernández- } \\
\text { Torrano1 et al., 2017) } \\
\end{array}$ & Kazakhastan & 52 & Ug, Mbbs & ILS & Visual and Sequential learning styles. \\
\hline 7 & $\begin{array}{l}\text { (Shama Mashhood } \\
\text { et al., 2017) }\end{array}$ & Pakistan & 210 & Ug, Mbbs & VARK & kinesthetic \\
\hline 8 & $\begin{array}{l}\text { (Rahila Nizami } \\
\text { et al., 2017) }\end{array}$ & Pakistan & 120 & $\begin{array}{l}\text { Ug, Dpt, } \\
\text { Mbbs }\end{array}$ & $\begin{array}{l}\text { Honey and Mumford, } \\
\text { LSQ }\end{array}$ & $\begin{array}{l}\text { Both the groups have Reflector as } \\
\text { dominating learning style }\end{array}$ \\
\hline$\overline{9}$ & $\begin{array}{l}\text { (Salilthip Paiboonsi- } \\
\text { thiwong1e et al., 2016) }\end{array}$ & Thailand & 140 & Ug, Mbbs & VARK & Quadmodal \\
\hline 10 & $\begin{array}{l}\text { (Myo Kyi Tha } \\
\text { et al., 2015) }\end{array}$ & Thailand & 65 & Ug, Mbbs & $\begin{array}{l}\text { Kolb's LSI, } \\
\text { Version 3.1. }\end{array}$ & Diverging and Assimilating \\
\hline 11 & $\begin{array}{l}\text { (Siaw-Cheok Liew } \\
\text { et al., 2015) }\end{array}$ & Malaysia & 419 & $\mathrm{Ug}, \mathrm{Dpt}$ & VARK & Unimodal Kinesthetic type. \\
\hline 12 & $\left(\right.$ D Hess et al., 2014) ${ }^{37}$ & South Africa & 246 & Ug, Dpt & ILS, LSQ, PSSQ & $\begin{array}{l}\text { Feeling for (PSSQ), kinesthetic for } \\
\text { (LSQ) and visual-verbal for (ILS). }\end{array}$ \\
\hline 13 & $\begin{array}{l}\text { (Hadi Peyman } \\
\text { et al., 2014) }\end{array}$ & Iran & 231 & Ug, Mbbs & VARK & Aural and reading/writing. \\
\hline 14 & $\begin{array}{l}\text { (Mohamed A. Al } \\
\text { Maghraby et al., 2013) }\end{array}$ & Saudi Arabia & 53 & $\mathrm{Ug}, \mathrm{Dpt}$ & $\begin{array}{l}\text { Gregorc Style } \\
\text { Delineator }\end{array}$ & concrete-sequential learning style \\
\hline 15 & $\begin{array}{l}\text { (Irfan Shukret } \\
\text { al., 2013) }\end{array}$ & Pakistan & $\begin{array}{l}\text { Group 1:85, } \\
\text { Group 2: } 85\end{array}$ & $\begin{array}{l}\text { Ug, Pg, } \\
\text { Mbbs }\end{array}$ & $\begin{array}{l}\text { Honey and Mumford, } \\
\text { LSQ }\end{array}$ & $\begin{array}{l}\text { UG student's activist, PG student's } \\
\text { reflector, theorist. Pragmatist in both }\end{array}$ \\
\hline 16 & $\begin{array}{l}\text { (Steve Milanese } \\
\text { et al., 2013) }\end{array}$ & Australia & 54 & $\mathrm{Ug}, \mathrm{Dpt}$ & Kolb's LSI, Version 3.1 & $\begin{array}{l}\text { Converging, Assimilating and } \\
\text { Accommodating }\end{array}$ \\
\hline
\end{tabular}

UG: undergraduate, PG: Post graduate, DPT: Doctor of Physical Therapy, MBBS: Bachelor of Medicine and Bachelor of Surgery

preference among participants from 2012 to 2021 and these the most commonly used questionnaire was VARK (Visual, Aural, Reading/ writing, Kinesthetic) which was used in six studies followed by Honey and Mumford used in three studies and among six studies two used Kolbs learning style inventory, two used the Grasha-Riechmann learning style scale and two studies used Index of learning style. While only one study used Gregorc Style Delineator.

Self-confidence in evidence based physical therapy is increasing as time passes. In this review, an expert panel used the Delphi methodology which was developed by Downes MJ, et al. for the methodological quality of the studies which was appraised critically by the Axis Tool.

The VARK questionnaire is one of the most widely used methods for defining and evaluating various sensory learning approaches. Among the studies the preferred style was Unimodal and among the learners who had unimodal style, the Kinesthetic $(\mathrm{K})$ type was found to be in the majority in five studies while one study claimed to have Quadmodal as 
Table 2: Methodological quality of articles: Critical Appraisal

\begin{tabular}{|c|c|c|c|c|c|c|c|c|c|c|c|c|c|c|c|c|c|c|}
\hline \multirow{2}{*}{$\begin{array}{l}\text { Study Author } \\
\text { (Latest to old) }\end{array}$} & \multicolumn{6}{|c|}{ Quality of reporting } & \multicolumn{6}{|c|}{ Quality of study design } & \multicolumn{6}{|c|}{ Possible biases in study } \\
\hline & 01 & 04 & 10 & 11 & 12 & 18 & 02 & 03 & 05 & 08 & 17 & 20 & 06 & 07 & 09 & 13 & 14 & 15 \\
\hline $\begin{array}{l}\text { (WNI Kularathne } \\
\text { et al., 2020) }\end{array}$ & \multicolumn{6}{|c|}{$\begin{array}{l}\text { All the points in quality of reporting were } \\
\text { mentioned in the article except } 18 \text {, the } \\
\text { limitations of the study were not discussed }\end{array}$} & \multicolumn{6}{|c|}{$\begin{array}{l}\text { All the points for Quality of study design } \\
\text { were mentioned except for } 19 \text { in which } \\
\text { neither funding sources were mentioned } \\
\text { nor any conflicts of interest. }\end{array}$} & \multicolumn{6}{|c|}{$\begin{array}{l}\text { The possible bias in this study is that } \\
\text { appropriate information about non- } \\
\text { responders were not described. }\end{array}$} \\
\hline $\begin{array}{l}\text { (Amtul Anum et } \\
\text { al., 2019) }\end{array}$ & \multicolumn{6}{|c|}{$\begin{array}{l}\text { All the related points were mentioned } \\
\text { hence representing a good quality of } \\
\text { reporting. }\end{array}$} & \multicolumn{6}{|c|}{$\begin{array}{l}\text { All the points for Quality of study design } \\
\text { were mentioned except for } 19 \text { in which } \\
\text { neither funding sources were mentioned } \\
\text { nor any conflicts of interest. }\end{array}$} & \multicolumn{6}{|c|}{$\begin{array}{l}\text { The possible bias in this study is that } \\
\text { appropriate information about non- } \\
\text { responders were not described. }\end{array}$} \\
\hline $\begin{array}{l}\text { (Assad Ali } \\
\text { Rezigalla et al., } \\
2018)^{3}\end{array}$ & \multicolumn{6}{|c|}{$\begin{array}{l}\text { The quality of reporting is good as all the } \\
\text { points are well addressed. }\end{array}$} & \multicolumn{6}{|c|}{$\begin{array}{l}\text { The quality of the study design is good } \\
\text { as all the points are well addressed. There } \\
\text { was no conflict of interest. }\end{array}$} & \multicolumn{6}{|c|}{$\begin{array}{l}\text { There were no possible biases found in } \\
\text { this study. }\end{array}$} \\
\hline $\begin{array}{l}\text { (D A Shead et al., } \\
\text { 2018) }\end{array}$ & \multicolumn{6}{|c|}{$\begin{array}{l}\text { The quality of reporting is good as all the } \\
\text { points are well addressed. }\end{array}$} & \multicolumn{6}{|c|}{$\begin{array}{l}\text { The quality of the study design is good } \\
\text { as all the points are well addressed. There } \\
\text { was no conflict of interest but there were } \\
\text { funding sources. }\end{array}$} & \multicolumn{6}{|c|}{$\begin{array}{l}\text { The possible bias in this study is that } \\
\text { appropriate information about non- } \\
\text { responders were not described and } \\
\text { response rate for the group one was low. }\end{array}$} \\
\hline $\begin{array}{l}\text { (Nursen Ýlçin et } \\
\text { al., 2018) }\end{array}$ & \multicolumn{6}{|c|}{$\begin{array}{l}\text { The quality of reporting is good as all the } \\
\text { points are well addressed. }\end{array}$} & \multicolumn{6}{|c|}{$\begin{array}{l}\text { All the points for Quality of study design } \\
\text { were mentioned and there was neither } \\
\text { funding sources nor any conflicts of } \\
\text { interest. }\end{array}$} & \multicolumn{6}{|c|}{$\begin{array}{l}\text { There were no possible biases found in } \\
\text { this study. }\end{array}$} \\
\hline $\begin{array}{l}(\text { Daniel } \\
\text { Hernández- } \\
\text { Torrano1 et al., } \\
2017)^{32}\end{array}$ & \multicolumn{6}{|c|}{$\begin{array}{l}\text { The quality of reporting is good as all the } \\
\text { points are well addressed. }\end{array}$} & \multicolumn{6}{|c|}{$\begin{array}{l}\text { All the points for Quality of study design } \\
\text { were mentioned and there was neither } \\
\text { funding sources nor any conflicts of } \\
\text { interest. }\end{array}$} & \multicolumn{6}{|c|}{$\begin{array}{l}\text { The possible bias in this study is that } \\
\text { appropriate information about non- } \\
\text { responders were not addressed and } \\
\text { described. }\end{array}$} \\
\hline $\begin{array}{l}(\text { Shama } \\
\text { Mashhood et al., } \\
2017)^{33}\end{array}$ & \multicolumn{6}{|c|}{$\begin{array}{l}\text { All the points in quality of reporting were } \\
\text { mentioned in the article except 18, the } \\
\text { limitations of the study were not discussed. }\end{array}$} & \multicolumn{6}{|c|}{$\begin{array}{l}\text { All the points for Quality of study design } \\
\text { were mentioned and there was neither } \\
\text { funding sources nor any conflicts of interest. }\end{array}$} & \multicolumn{6}{|c|}{$\begin{array}{l}\text { There were no possible biases found in } \\
\text { this study. }\end{array}$} \\
\hline $\begin{array}{l}\text { (Rahila Nizami et } \\
\text { al., 2017) }\end{array}$ & \multicolumn{6}{|c|}{$\begin{array}{l}\text { statistical significance, methods and } \\
\text { limitations were not properly reported } \\
\text { leading to low quality of reporting }\end{array}$} & \multicolumn{6}{|c|}{$\begin{array}{l}\text { statistical significance, methods and } \\
\text { limitations were not properly reported } \\
\text { leading to low quality of reporting }\end{array}$} & \multicolumn{6}{|c|}{$\begin{array}{l}\text { The possible bias in this study is that } \\
\text { appropriate information about non- } \\
\text { responders were not addressed and } \\
\text { described. }\end{array}$} \\
\hline $\begin{array}{l}\text { (Salilthip } \\
\text { Paiboonsithiwon } \\
\text { g1e et al., 2016) }\end{array}$ & \multicolumn{6}{|c|}{$\begin{array}{l}\text { The quality of reporting is good as all the } \\
\text { points are well addressed. }\end{array}$} & \multicolumn{6}{|c|}{$\begin{array}{l}\text { The quality of the study design is good } \\
\text { as all the points are well addressed. There } \\
\text { was no conflict of interest but there were } \\
\text { funding sources. }\end{array}$} & \multicolumn{6}{|c|}{$\begin{array}{l}\text { The possible bias in this study is that } \\
\text { appropriate information about non- } \\
\text { responders were not described and } \\
\text { response rate was not mentioned. }\end{array}$} \\
\hline $\begin{array}{l}\text { Myo Kyi Tha et } \\
\text { al., 2015) }\end{array}$ & $\begin{array}{l}\text { The } \\
\text { point }\end{array}$ & ality & $\mathrm{fre}$ & rting & goo & d as all the & $\begin{array}{l}\text { The } \\
\text { as all } \\
\text { was } 1 \\
\text { fund }\end{array}$ & $\begin{array}{l}\text { qualit } \\
1 \text { the p } \\
\text { no con } \\
\text { ing so }\end{array}$ & ict $\mathrm{c}$ & st & de & $\begin{array}{l}n \text { is good } \\
\text { ed. There } \\
\text { here were }\end{array}$ & & & & ble 1 & $\operatorname{ses} f$ & d in \\
\hline $\begin{array}{l}\text { (Siaw-Cheok } \\
\text { Liew et al., 2015) }\end{array}$ & $\begin{array}{l}\text { The } \\
\text { point }\end{array}$ & lit & & & goo & as all the & $\begin{array}{l}\text { The } \\
\text { as all } \\
\text { was } 1 \\
\text { fund }\end{array}$ & $\begin{array}{l}\text { qualit } \\
1 \text { the } \mathrm{p} \\
\text { no con } \\
\text { ing so }\end{array}$ & ict o & vel & des & $\begin{array}{l}\text { is good } \\
\text { ed. There } \\
\text { lere were }\end{array}$ & & & & und & his & $\begin{array}{l}y \text { is } \\
1 \text {. }\end{array}$ \\
\hline $\begin{array}{l}(\mathrm{D} \text { Hess et al., } \\
2014)^{37}\end{array}$ & $\begin{array}{l}\text { The } \\
\text { point }\end{array}$ & $\begin{array}{l}\text { ality } \\
\text { are }\end{array}$ & $\mathrm{fr}$ & tino & goo & d as all the & $\begin{array}{l}\text { The } \\
\text { as all } \\
\text { was 1 } \\
\text { there }\end{array}$ & $\begin{array}{l}\text { qualit } \\
1 \text { the p } \\
\text { no con } \\
\text { e were }\end{array}$ & to & ter & $\mathrm{t}$ me & $\begin{array}{l}\text { is good } \\
\text { ed. There } \\
\text { ioned but }\end{array}$ & & & & ble 1 & es $\mathrm{f}$ & $\mathrm{d}$ in \\
\hline $\begin{array}{l}\text { (Hadi Peyman et } \\
\text { al., 2014) }\end{array}$ & $\begin{array}{l}\text { All t } \\
\text { henc } \\
\text { repol }\end{array}$ & rel & ed & nts & ere 1 & $\begin{array}{l}\text { entioned } \\
\text { uality of }\end{array}$ & $\begin{array}{l}\text { All tl } \\
\text { were } \\
\text { neith } \\
\text { nor a }\end{array}$ & $\begin{array}{l}\text { he poi } \\
\text { e ment } \\
\text { er fun }\end{array}$ & ng & ce & ere & $\begin{array}{l}\text { dy design } \\
\text { in which } \\
\text { eentioned }\end{array}$ & & & & le 1 & s 1 & $\mathrm{~d}$ in \\
\hline $\begin{array}{l}\text { (Mohamed A. Al } \\
\text { Maghraby et al., } \\
2013)^{39}\end{array}$ & $\begin{array}{l}\text { All t } \\
\text { henc } \\
\text { repor }\end{array}$ & ting. & . & 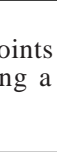 & $\begin{array}{l}\text { ere } 1 \\
\text { ood }\end{array}$ & $\begin{array}{l}\text { mentioned } \\
\text { quality of }\end{array}$ & $\begin{array}{l}\text { All tl } \\
\text { were } \\
\text { neith } \\
\text { nor a }\end{array}$ & $\begin{array}{l}\text { he poi } \\
\text { e ment } \\
\text { er fun } \\
\text { any co }\end{array}$ & $f$ & 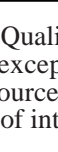 & ere & $\begin{array}{l}\text { dy design } \\
\text { in which } \\
\text { entioned }\end{array}$ & $\begin{array}{l}\text { The } \\
\text { was } \\
\text { and } \\
\text { cate } \\
\text { info }\end{array}$ & $\begin{array}{l}\text { n- re } \\
\text { ized }\end{array}$ & de & $\begin{array}{l}\text { nse } \\
\text { ere } \\
\text { was }\end{array}$ & $\begin{array}{l}\text { men } \\
\text { addr } \\
\text { appro }\end{array}$ & $\begin{array}{l}\text { tudy } \\
\text { oned } \\
\text { sed, } \\
\text { riate }\end{array}$ \\
\hline $\begin{array}{l}\text { (Irfan Shukret al., } \\
2013)^{10}\end{array}$ & $\begin{array}{l}\text { The } \\
\text { point }\end{array}$ & are & 1 & ares & go & as all the & $\begin{array}{l}\text { All tl } \\
\text { were } \\
\text { neith } \\
\text { nor a }\end{array}$ & $\begin{array}{l}\text { he poi } \\
\text { ment } \\
\text { her fun }\end{array}$ & no & ep & ere & $\begin{array}{l}\text { dy design } \\
\text { in which } \\
\text { lentioned }\end{array}$ & & & & $\begin{array}{l}\text { ound } \\
\text { not } 1 \\
\text { and }\end{array}$ & $\begin{array}{l}\text { his } \\
\text { tior } \\
\text { are }\end{array}$ & $\begin{array}{l}\text { dy is } \\
\text { Due }\end{array}$ \\
\hline $\begin{array}{l}(\text { Steve Milanese et } \\
\text { al., 2013) }\end{array}$ & $\begin{array}{l}\text { All tl } \\
\text { ment } \\
\text { limit: }\end{array}$ & poir & f the & glit & $\begin{array}{l}\text { repc } \\
\text { exce } \\
\text { e not }\end{array}$ & $\begin{array}{l}\text { orting were } \\
\text { ept } 18 \text {, the } \\
\text { t discussed. }\end{array}$ & $\begin{array}{l}\text { The } \\
\text { as all } \\
\text { was } \\
\text { sourc }\end{array}$ & $\begin{array}{l}\text { qualit } \\
1 \text { the p } \\
\text { no co } \\
\text { ces. }\end{array}$ & of $t$ & stu & $\mathrm{de}$ & $\begin{array}{l}n \text { is good } \\
\text { ed. There } \\
\text { funding }\end{array}$ & & udy & & le & s & d in \\
\hline
\end{tabular}


Flow chart showing number of studies included according to PRISMA guidelines for systematic review

Figure 1: Preferred Reporting Item for Systematic Review and meta-analysis (PRISMA) flow-chart

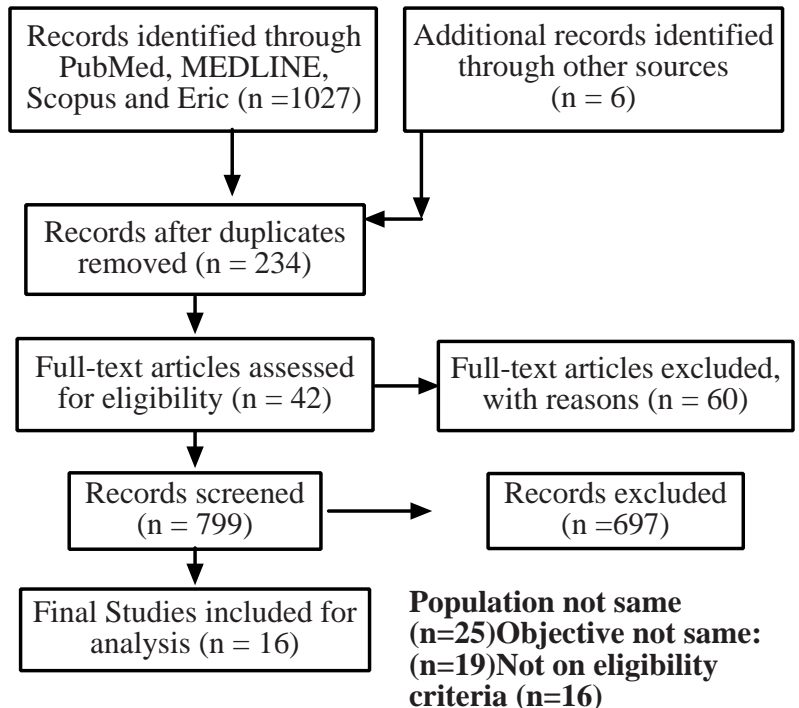

preferred learning style. Quadmodal learning was the most popular among medical students. Our findings are consistent with Almigbal and Liew et al. ${ }^{18,19}$

The majority of the students were unimodal, according to both previous and recent findings. Meanwhile, old local studies have found that the dominant type is multimodal, which contradicts the current data. The VARK (Visual, Aural, Reading/ writing, Kinesthetic) questionnaire is widely used due to its validity and reliability, as well as its ease of use and free availability. ${ }^{21}$

The results were found to be mixed on the predominance of the international data on multimodal and unimodal patterns of learning style. The dominance of multimodal was reported by Murphy et al and EL Tantowi from the United States ${ }^{22,23}$ ${ }^{22,23}$ as well as Baykan from Turkey. ${ }^{2424}$ While Pakistan's Siddiqi et al and Haq et al supported the unimodal dominance. $^{22-25}$

Three studies that used Honey and Mumford learning style had Activist as the majority of the respondent's style among them $(51.2 \%)$. In another study, Reflector was the most popular learning style among both groups, while Pragmatist is the second most popular learning style (16.7\%). The last study included both undergrad and postgrad students in which Undergraduate students preferred being an activist $45 \%$, whereas postgraduate students preferred reflector (38 $\%)$ and theorist $(35 \%)$.

The true purpose of identifying these various learning styles is to have matching teaching strategies and appropriate assessment methods. When four different learning styles are present in a class, it stipulates that a single teaching methodology is ineffective for the entire group. When planning for teaching and learning activities, keep the preferred learning style in mind. Honey and Mumford learning styles can be used to map a class and create a teaching strategy that works.

Two studies that used Kolb's learning style inventory had Assimilating style frequent in both of them. In which Assimilating and Diverging styles were the largest groups of the study population $(30.8 \%)$, while in the other studies the preferences of learning style were evenly dispersed among the three learning styles which were Converging, Assimilating, and Accommodating, with diverging style as the least preferred one.

The Grasha-Riechmann study in which physiotherapy students' learning styles are consistent and compatible with lecturers' teaching styles, resulting in better learning outcomes. The dependent style was the most popular choice for group 1 and the independent style was the most popular choice for group 2. While in the other study in which the relationship between learning styles and educational accomplishment was to be researched had the most common learning style as to be Collaborative.

According to the previous research, physiotherapy students preferred abstract learning styles. As well as having desirable study methods ${ }^{27}$ Converger (40\%) and Assimilator (35\%) learning styles were preferred by physiotherapy students in Canada and the United States, respectively. ${ }^{28}$

In the two studies which used the Index of learning style among them the visual-verbal aspect of learning style was more common. The Learning style among students which were presented in 2 groups of first-year medical students had their learning styles analyzed across four dimensions: verbal-visual, reflective-active, sequential-global, and intuitive-sensing. There was very little difference when the results were analyzed. The number of students who preferred sensing $(54.9 \%)$ versus intuitive $(45.1 \%)$ learning styles, as well as those who preferred reflective $(49.1 \%)$ versus active $(50.9 \%)$ learning styles.

Only one study has used Gregorc Style Delineator, where, even though there are mixed styles of other styles, most physical therapist students preferred concrete-sequential learning styles. The majority of those students also preferred the random training, digital media activities, advanced organisers and demonstrations. Further studies should be conducted with various parameters like learning style with academic performances, gender influences, and among different demographic participants. This study only contained undergraduate students of MBBS and Doctor of Physical Therapy among all the Allied health and medical students. Further research should concentrate on defining and describing physiotherapy and MBBS learning styles in such a way that they can be used as an industry standard, as well as developing valid and reliable learning style outcome 
measures that are applicable across physiotherapy and MBBS learners and settings. Also, more research is needed to determine whether there is a correlation of learning style preferences with teaching styles learning strategies. In addition, a longitudinal study would be compelling to see how the learning style changes with time and its influence on the students' performance within a specific field.

\section{CONCLUSION:}

All studies supported learning style among the students and the most commonly used learning style questionnaire is VARK (Visual, Aural, Reading/ writing, Kinesthetic). In conclusion, this study affirms the heterogeneity in students' learning preferences. Among them, the most preferred learning style is kinaesthetic and activist. That state's learning is based on experiments, hands-on practice, audio-visual lectures, teaching sessions in a new environment allowing students to analyze and synthesize theories. However, students require adaptable, educative, and assessment strategies as they have different learning styles. In order to further investigate the valid and reliable outcome of learning styles applicable across physiotherapy and MBBS, it should be defined and described in a way that can be used in the health discipline as a standard.

Acknowledgement: I am very grateful to Dr. Fahad Tanveer, Dr. Amber, and Dr. Saba Ali for their kind encouragement, constructive criticism and sympathetic suggestions which made me expeditious in my achievements.

Authors Contribution:
Sarwat Ali: Original idea, Literature search, Manuscript write
up, data collection, final layout
I Ashfaq Ahmad: Final approval of the version to be published, I
agreement to be accountable for all aspects, revising it critically I
Arooj Munawar: Final analysis and drafting the article
Muhammad Waqas: Data interpretation, critical review, proof I
reading

\section{REFERENCES:}

1. Baykan Z, Naçar M. Learning styles of first-year medical students attending Erciyes University in Kayseri, Turkey. Advances in Physiology Education. 2007; 31(2): 158-60. DOI:610.1152/advan.00043.2006.

2. Griffiths C, Ýnceçay G. Styles and style-stretching: How are they related to successful learning? Journal of psycholinguistic research. 2016; 45(3): 599-613. DOI: 10. 1007/s10936-015-9366-2.

3. Rezigalla AA, Ahmed OY. Learning style preferences among medical students in the College of Medicine, University of Bisha, Saudi Arabia (2018). Advances in medical education and practice. 2019; 10: 795-801. DOI: 10.2147/ AMEP. S219176.

4. Hussein Ibrahim R, Hussein DA-r. Assessment of visual, auditory, and kinesthetic learning style among undergraduate nursing students. International Journal of Advanced Nursing Studies. 2015; 5(1): 1. DOI: 10.14419/ijans.v5i1.5124

5. Bostanci Ö. Learning Style Preferences of Prospective Teachers of Physical Education and Sport. 2020; 6(2): 2316 DOI: 10.20448/journal.522.2020.62.231.236.
6. Vizeshfar F, Torabizadeh C. The effect of teaching based on dominant learning style on nursing students' academic achievement. Nurse education in practice. 2018; 28: 103-8. DOI: 10.1016/j.nepr.2017.10.013.

7. Al-Saud LM. Learning style preferences of first-year dental students at King Saud University in Riyadh, Saudi Arabia: influence of gender and GPA. Journal of dental education. 2013; 77(10): 1371-8.

8. Cassidy * S. Learning Styles: An overview of theories, models, and measures. Educational Psychology. 2004; 24(4): 419-44. DOI: $10.1080 / 0144341042000228834$

9. Buali WH, Balaha MH, Muhaidab NS. Assessment of learning style in a sample of saudi medical students. Acta informatica medica : AIM : journal of the Society for Medical Informatics of Bosnia \& Herzegovina : casopis Drustva za medicinsku informatiku BiH. 2013; 21(2): 83-8. DOI: 10.5455/aim .2013.21.83-88.

10. Shukr I, Zainab R, Rana MH. Learning styles of postgraduate and undergraduate medical students. Journal of the College of Physicians and Surgeons--Pakistan : JCPSP. 2013; 23(1): 25-30.

11. Anum A, Qadeer TA. Differences In Learning Preferences Among Medical, Dental And DPT Students. Journal of Bahria University Medical \& Dental College. 2019: 222.

12. Hosford CC, Siders WA. Felder-Soloman's Index of Learning Styles: internal consistency, temporal stability, and factor structure. Teaching and learning in medicine. 2010; 22(4): 298-303. DOI: 10.1080/10401334.2010.512832.

13. Aaron S, Skakun E. Correlation of students' characteristics with their learning styles as they begin medical school. Academic medicine : journal of the Association of American Medical Colleges. 1999; 74(3): 260-2. DOI: 10.1097/ 00001888-199903000-00016.

14. Tariq S, Khan MA, Afzal S, Shahzad SR, Hamza M, Khan $\mathrm{HA}$, et al. Association between academic learning strategies and annual examination results among medical students of King Edward Medical University. Annals of King Edward Medical University. 2016; 22(2). DOI: https://doi.org /10.21649/akemu.v22i2.1290

15. Page MJ, McKenzie JE, Higgins JPT. Tools for assessing risk of reporting biases in studies and syntheses of studies: a systematic review. BMJ Open. 2018; 8(3): e019703-e. DOI: 10.1136/bmjopen-2017-019703.

16. Downes MJ, Brennan ML, Williams HC, Dean RS. Development of a critical appraisal tool to assess the quality of cross-sectional studies (AXIS). BMJ Open. 2016; 6(12): e011458. DOI: 10.1136/bmjopen-2016-011458.

17. Ma L-L, Wang Y-Y, Yang Z-H, Huang D, Weng H, Zeng XT. Methodological quality (risk of bias) assessment tools for primary and secondary medical studies: what are they and which is better? Military Medical Research. 2020; 7(1): 7. DOI: 10.1186/s40779-020-002388.

18. Almigbal TH. Relationship between the learning style preferences of medical students and academic achievement. Saudi medical journal. 2015; 36(3): 349-55. DOI: 10.15537 /smj.2015.3.10320.

19. Liew SC, Sidhu J, Barua A. The relationship between learning preferences (styles and approaches) and learning outcomes among pre-clinical undergraduate medical students. BMC medical education. 2015; 15: 44. DOI: 10.1186/s12909-0150327-0. 
20. Nuzhat A, Salem RO, Al Hamdan N, Ashour N. Gender differences in learning styles and academic performance of medical students in Saudi Arabia. Medical teacher. 2013; 35 Suppl 1: S78-82. DOI: 10.3109/0142159X.2013.765545.

21. El-Aziz El Naggar M. Identifying and comparing learning styles preferences among medical undergraduates students at college of medicine Aljouf University. Intel Prop Rights S. 2016; 1: 2. DOI: 10.4172/2375-4516.S1-011

22. Murphy RJ, Gray SA, Straja SR, Bogert MC. Student learning preferences and teaching implications. Journal of dental education. 2004; 68(8): 859-66.

23. El Tantawi MM. Factors affecting postgraduate dental students' performance in a biostatistics and research design course. Journal of dental education. 2009; 73(5): 614-23.

24. Baykan Z, Naçar M. Learning styles of first-year medical students attending Erciyes University in Kayseri, Turkey. Advances in physiology education. 2007; 31(2): 158-60. DOI: 6 10.1152/advan.00043.2006.

25. Rehan R, Farooqi L, Khan H, Rehman R. Comparison of two interactive tutorial methods: results from a medical college in Karachi. JPMA The Journal of the Pakistan Medical Association. 2017; 67(2): 196-9.

26. Barris R, Kielhofner G, Bauer D. Learning preferences, values, and student satisfaction. Journal of allied health. 1985; 14(1): 13-23.

27. Van Langenberghe HV. Evaluation of students' approaches to studying in a problem-based physical therapy curriculum. Physical therapy. 1988; 68(4): 522-9. DOI: 10.1093/ ptj/68. 4.522 .

28. Wessel J, Loomis J, Rennie S, Brook P, Hoddinott J, Aherne $\mathrm{M}$. Learning styles and perceived problem-solving ability of students in a baccalaureate physiotherapy programme. Physiotherapy theory and practice. 1999; 15(1): 17-24. DOI: 10.1080/095939899307865

29. Kularathne W, Bandara E, Prasanna A. Learning style preferences and academic performance of undergraduate physiotherapy students. 13Th International Research Conference; 2020; 2020. p. 57. DOI: http://ir.kdu.ac.lk/ handle/345/2894

30. Shead DA, Roos R, Olivier B, Ihunwo AO. Learning styles of physiotherapy students and teaching styles of their lecturers in undergraduate gross anatomy education; 2018. DOI: 10.7196/AJHPE.2018.v10i4.1070
31. Ýlçin N, Tomruk M, Yepilyaprak SS, Karadibak D, Savcý S. The relationship between learning styles and academic performance in TURKISH physiotherapy students. BMC medical education. 2018; 18(1): 291. DOI: 10.1186/s12909018-1400-2.

32. Hernández-Torrano D, Ali S, Chan CK. First year medical students' learning style preferences and their correlation with performance in different subjects within the medical course. BMC medical education. 2017; 17(1): 131. DOI: 10.1186 /s12909-017-0965-5.

33. Mashhood S, Mashhood-uz-Zafar Farooq MF, Fahim MK. Medical student's preferred learning style. Pak J Surg. 2018; 34(1): 36-40.

34. Nizami R, Latif MZ, Wajid G. Preferred learning styles of medical and physiotherapy students. Annals of King Edward Medical University. 2017; 23(1). DOI: https://doi.org/ 10.21649/akemu.v23i1.1511

35. Paiboonsithiwong S, Kunanitthaworn N, Songtrijuck N, Wongpakaran N, Wongpakaran T. Learning styles, academic achievement, and mental health problems among medical students in Thailand. Journal of educational evaluation for health professions. 2016; 13: 38. DOI: 10.3352/ jeehp.2016. 13.38 .

36. Tha MK, Khin N. Learning Styles of Undergraduate Medical Students: Using the Kolb Learning Style Inventory. MedEdPublish. 2015. DOI: 10.15694/mep.2015.004.0015

37. Hess D, Frantz JM. Understanding the learning styles of undergraduate physiotherapy students. African Journal of Health Professions Education. 2014; 6(1): 45-7.

38. Peyman H, Sadeghifar J, Khajavikhan J, Yasemi M, Rasool M, Yaghoubi YM, et al. Using VARK Approach for Assessing Preferred Learning Styles of First Year Medical Sciences Students: A Survey from Iran. Journal of clinical and diagnostic research : JCDR. 2014; 8(8): Gc01-4. DOI: 10.7860/JCDR /2014/8089.4667.

39. Al Maghraby MA, Alshami AM. Learning style and teaching method preferences of Saudi students of physical therapy. Journal of family \& community medicine. 2013; 20(3): 1927. DOI: $10.4103 / 2230-8229.122017$.

40. Milanese S, Gordon S, Pellatt A. Profiling physiotherapy student preferred learning styles within a clinical education context. Physiotherapy. 2013; 99(2): 146-52. DOI: 10.1016/j. physio.2012.05.004. 